\title{
Somatic embryogenesis of Quercus suber L. from immature zygotic embryos
}

Pilar S. Testillano ${ }^{1, *}$, Aránzazu Gómez-Garay ${ }^{2}$, Beatriz Pintos ${ }^{2}$, María C. Risueño ${ }^{1}$

${ }^{1}$ Pollen Biotechnology of Crop Plants, Biological Research Centre, CIB-CSIC Ramiro de Maeztu 9, 28040 Madrid, Spain

${ }^{2}$ Department of Plant Biology I, Faculty of Biology, UCM, Madrid, Spain.

*Corresponding author

E-mail: testillano@cib.csic.es

Running title: Somatic embryogenesis of cork oak 


\begin{abstract}
Quercus suber L., cork oak, is a forest tree of high social and economic value. The cork is traditionally used in the wine industry to produce bottle-stoppers, but it is also a very good material for both thermal and acoustic insulation in construction. Since its harvest does not harm the tree, the use of cork in the industry has a positive impact on the environment.
\end{abstract}

Somatic embryogenesis is considered a feasible system for in vitro regeneration procedures, with many advantages in woody species. Classical genetic breeding programs have important limitations in forest trees, like cork oak, due to their long life span, and difficulties of seed conservation and vegetative reproduction. Therefore, somatic embryogenesis has a great potential for large-scale propagation and cryopreservation of elite genotypes, as well as for transformation strategies. In the case of $Q$. suber, several in vitro propagation systems through somatic embryogenesis have been reported, with different efficiency rate.

In the present chapter, updated information is reported about an efficient protocol for induction of somatic embryogenesis of $Q$. suber from immature zygotic embryos, as well as methods for proliferation and maturation of somatic embryos, germination, plantlet regeneration and acclimatization.

\title{
Key words:
}

Cork oak, somatic embryogenesis, plant cell reprogramming, embryogenic masses, embryo differentiation, embryo maturation.

\section{Introduction}

Quercus suber L., cork oak, is a forest tree of high social and economic value in southern Europe. The cork is a raw natural material traditionally used in the wine industry to produce bottle-stoppers. Moreover, since cork does not conduct either heat or sound well, it is a very good material for both thermal and acoustic insulation. Due to these properties, there is an increasing section of the cork market in which this material 
is employed to produce cork-based composite materials, with applications in construction and space industries. Another good property of cork is the fact that its harvest does not harm the tree, as the material is only separated from the trunk; therefore, the use of cork in the industry has a positive impact on the environment. All these properties have made cork at present as a material with much greater potential, already employed in many industrial sectors, with new applications being developed, and with a positive impact on the environment.

Somatic embryogenesis in vitro systems are very useful for biotechnological applications in plant breeding, propagation and conservation strategies [1,2]. Classical genetic breeding programs have important limitations in forest trees, like cork oak, due to their long life span, and difficulties of seed conservation and vegetative reproduction. Therefore, somatic embryogenesis has a great potential for large-scale propagation and cryopreservation of elite genotypes, as well as for transformation strategies. Induction of somatic embryogenesis has been reported in several Quercus species, like Quercus robur, $Q$. ilex, and $Q$. alba ([3-6]. In the case of $Q$. suber, several in vitro propagation systems through somatic embryogenesis have been reported, with different efficiency rate [7-9]. The effects on somatic embryogenesis efficiency of various culture conditions and medium components have been described [10,11], as well as changes in the proteome of cells during somatic embryogenesis of $Q$. suber $[12,13]$. Several studies on the cellular rearrangements and factors involved in the somatic embryogenesis induction and progression process have permitted to characterize the process at cellular level and to point out the relevance of epigenetic marks, like DNA methylation, pectins of cell wall, and endogenous phytohormones, especially auxin, in the induction and progression of in vitro embryogenesis of $Q$. suber [14-16].

In $Q$. suber, as in many other systems, somatic embryogenesis is a complex process, not completely understood yet, that begins with the induction process. After induction, some responsive cells of the explants are reprogrammed, acquire totipotency, follow the embryogenesis developmental pathway and produce embryos by direct somatic embryogenesis. In many in vitro systems, reprogrammed cells can also proliferate and originate masses of embryogenic cells that give rise to somatic embryos by indirect embryogenesis or continue proliferating and produce more embryogenic masses. Moreover, developing somatic embryos can in turn produce new embryos by recurrent 
secondary embryogenesis. This process permits the in vitro system to produce much more somatic embryos by cycling processes, and during longer time.

In the present chapter, updated information is reported about an efficient protocol for induction of somatic embryogenesis of $Q$. suber from immature zygotic embryos, as well as methods for proliferation and maturation of somatic embryos, germination, plantlet regeneration and acclimatization.

\section{Materials}

\subsection{Plant material}

1.Immature pollinated acorns were collected from Quercus suber L. (cork oak) trees every week during fruit development period (late August and September) from two selected trees in the E.T.S.I. de Montes (Universidad Politécnica de Madrid) and three selected trees from El Pardo, Madrid, Spain.

2.Immature acorns selected at the appropriate developmental stage (Note 1) for somatic embryogenesis induction are kept at $4^{\circ} \mathrm{C}$ for one week before in vitro culture initiation.

\subsection{Laboratory Equipment}

1.- Laminar flow hood for plant in vitro culture.

2.- Autoclave for sterilization.

3.- $\mathrm{pH}$ meter.

4.- General tissue culture laboratory equipments and tools: forceps, scalpels, magnetic stirrers, automatic pipettes, etc.

5.- Sterile Petri dishes of $90 \mathrm{~mm}$ diameter.

\subsection{Culture media mixtures}

1.- Micronutrients of MS medium [17] (Table 1) 
2.- Vitamins of MS medium [17] (Table 2)

3.- Macronutrients of Sommer medium [18] (Table 3)

\section{Methods}

\subsection{Culture media preparation}

1.Four solid culture media are prepared and used in the different steps of somatic embryogenesis: medium for induction, medium for proliferation, medium for maturation and medium for germination, with the composition detailed en Table 4.

2.The $\mathrm{pH}$ of the media is adjusted to 5.6. Culture media are supplemented, as indicated in the Table 4, with the growth regulator 2,4-D, glutamine and agar (Note 2).

3.After sterilization, medium is dispensed in Petri dishes and leave at room temperature to solidify. Plates are sealed with Parafilm and kept in sterile conditions until their use for in vitro culture.

\subsection{Explant excision and sterilization}

Immature zygotic embryos are carefully excised from the acorns by dissecting the surrounding tissues with the help of scalpel and forceps. Immature zygotic embryos are sterilized by immersion in $70 \%$ ethanol for $30 \mathrm{~s}$ and in $2 \%$ sodium hypochlorite for 20 min, followed by three rinses in sterile distilled water of 10 min each.

\subsection{Induction of somatic embryogenesis}

1.Immature zygotic embryos are first cultured in induction medium (Note 3), which contains $0.5 \mathrm{mg} / \mathrm{l}$ 2,4-D (Table 4), for one month at $25^{\circ} \mathrm{C}$ and $16 / 8 \mathrm{~h}$ light/darkness. During this induction period, cell reprogramming occurs in some responsive cells which initiate the embryogenesis pathway. 
2.By the fourth week of culture in induction medium, the responsive cells have reprogrammed, start to divide and give rise to clusters of proliferating cells that can originate embryogenic masses and small globular embryos, both types of structures appear at the surface of the explants, emerging from their interior. Embryogenic masses are rounded/nodular masses of cellular aggregates that arise from the explants after induction, as the first morphological sign of embryogenic response; they contain embryogenic cells that can give rise to somatic embryos by indirect embryogenesis or proliferate and produce more embryogenic masses. Globular embryos are small and rounded white structures with smooth surface, somatic embryos can be produced directly from reprogrammed cells of the explants (direct somatic embryogenesis) or from cells of the embryogenic masses (indirect somatic embryogenesis).

3. Microscopic analysis reveals that embryogenic cells and early embryo cells show typical features of active proliferating cells, i.e. small cell size, medium-large nucleus, slightly dense cytoplasm and low vacuolation.

\subsection{Multiplication of somatic embryogenic cultures}

1.After one month in induction medium, immature zygotic embryos are transferred to proliferation medium (Table 4), with the same composition but growth regulator-free (without 2,4-D). During the next weeks of culture in the proliferation medium, embryogenic masses proliferate and protrude from different parts of the explants; they produce new embryogenic masses and embryos, which in turn give rise to new embryos by recurrent somatic embryogenesis (Note 4).

2. To maintain the proliferation of the embryogenic masses, they are excised from explants and transferred to fresh proliferation medium every month. Monthly refreshed subcultures can be maintained in proliferation for several months, at $25^{\circ} \mathrm{C}$ and $16 / 8 \mathrm{~h}$ light/darkness.

3.Small embryos at globular, heart and torpedo stage, and embryogenic masses cultured in proliferation medium suffer recurrent somatic embryogenesis where new somatic embryos and embryogenic masses are originated from previously existing somatic embryos (Note 5). 
3.Some of these embryos stop recurrent embryogenesis, continue their development and differentiate as individual immature cotyledonary embryos which are translucent and 2$3 \mathrm{~mm}$ long, with two small cotyledons and an embryogenic axis.

\subsection{Maturation of somatic embryos}

1.Well-shaped immature cotyledonary embryos from plates of the proliferation medium are separated and cultured on maturation medium which has a basal composition (growth regulator-free) plus $1 \%$ activated charcoal (Table 4).

2.Immature cotyledonary embryos are cultured for a period of 4 weeks at $25^{\circ} \mathrm{C}$ in darkness. During this period, embryos accumulate reserve nutrient substances in cotyledons and increase their weight, giving rise to mature somatic embryos. Mature somatic embryos are larger (more than $8 \mathrm{~mm}$ length), opaque ivory-colored, with wellformed large cotyledons, embryogenic axis and hypocotyl.

\subsection{Germination of somatic embryos and conversion to plantlets}

1.Prior to transfer to germination medium, as a pre-treatment, mature embryos are incubated during to 2 months at $4^{\circ} \mathrm{C}$, in maturation medium.

2.For germination, mature somatic embryos are transferred to Petri dishes with germination medium which has less sucrose and higher agar concentrations than the maturation medium, and contains the growth regulators 6-benzylaminopurine, BA, and indole-3-butyric acid, IBA (Table 4) (Note 6)

2.Somatic embryos are maintained in Petri dishes with germinating medium at $25^{\circ} \mathrm{C}$ and 16h light conditions for several weeks. During this period, embryos start to germinate, develop radicle and turn the colour of cotyledons to green.

3.When embryos exhibit a well developed radicle and green cotyledons, they are transferred individually to a glass culture vessel with germinating medium under the 
same culture conditions, where they have better conditions and more space for further growth.

\subsection{Hardening and acclimatization}

1. Germinating somatic embryos are cultured for 6-8 weeks in vessels where they develop true leaves and a more complex root system, with small lateral roots, and give rise to plantlets that growth during this period.

2.In vitro-rooted plantlets are carefully extracted from vessels, washed to remove the agar and then cultured ex-vitro for hardening and acclimatization. They are first transferred to trays with a sterile potting mix of peat:vermiculite, $3: 1$; trays are covered with a transparent cover to maintain a high humidity environment, and maintained in a growth chamber with controlled temperature and photoperiod $\left(25^{\circ} \mathrm{C}\right.$ and $16 \mathrm{~h}$ light $)$.

3.Finally, plants are transferred to pots with the same peat:vermiculite mix and put in the greenhouse.

\section{Notes}

1. The immature acorns that are most appropriate/responsive to somatic embryogenesis induction are those with small size, around $1 \mathrm{~cm}$ diameter, and green colour; they contain immature zygotic embryos at the early cotyledonary stage.

2. The $\mathrm{pH}$ of the media is adjusted to 5.6 with $\mathrm{NaOH}$ prior to adding the solidifying agent (agar). Growth regulators and agar are added before autoclaving, and after that, glutamine is added by filter-sterilization, using filters of $0.22 \mu \mathrm{m}$.

3. Induction medium is dispensed in $90 \mathrm{~mm}$ Petri dishes (around $25 \mathrm{ml}$ per dish), and 5 immature zygotic embryos (previously sterilized) are place per Petri dish. 
4. Since development is asynchronous and recurrent secondary embryogenesis can happen any time in each individual embryo, plates of proliferation medium usually exhibit a wide repertoire of embryogenic masses of different sizes and somatic embryos at various developmental stages, from early globular, torpedo till immature cotyledonary embryos.

5. Somatic embryogenesis cultures in the proliferation medium maintain their embryogenic capacity for many months and are used as a continuous source of new somatic embryos.

6. To promote germination, partial desiccation of mature embryos can be performed prior to transfer to germination medium, although it can be achieved without this pretreatment.

\section{Acknowledgements}

Work supported by projects funded by the Spanish Ministry of Economy and Competitiveness, MINECO, and the European Regional Development Fund (ERDF/FEDER) of the European Commission (BFU2011-23752, AGL2014-52028).

\section{References}

1. Germaná MA, Lambardi M (2016) In vitro embryogenesis in higher plants, vol 1359. Methods in Molecular Biology. Humana Press-Springer, NY, Heidelberg

2. Loyola-Vargas VM, Ochoa-Alejo N (2016) Somatic Embryogenesis: Fundamental Aspects and Applications Springer Verlag, NY, Heidelberg

3. Maury PV, Manzanera JA (2003) Induction, maturation and germination of holm oak (Quercus ilex L.). Plant Cell Tissue and Organ Culture 74:229-235

4. Corredoira E, Toribio M, Vieitez E (2014) Clonal propagation via somatic embryogenesis in Quercus spp. In: Ramawhat KG; Mérillon, J.M.; Ahuja, M.R. (eds) Tree Biotechnology. CRC Press, Boca Raton, USA, pp 262-302 
5. Corredoira E, Cano V, Bárány I, Solís MT, Rodríguez H, Vieitez AM, Risueño MC, Testillano PS (2017) Initiation of leaf somatic embryogenesis involves high pectin esterification, auxin accumulation and DNA demethylation in Quercus alba. J Plant Physiol 213:42-54. doi:10.1016/j.jplph.2017.02.012

6. Barra-Jiménez A, Blasco M, Ruiz-Galea M, Celestino C, Alegre J, Arrillaga I, Toribio M (2014) Cloning mature holm oak trees by somatic embryogenesis. Trees-Structure and Function 28 (3):657-667.

7. Bueno MA, Astorga R, Manzanera JA (1992) Plant regeneration through somatic embryogenesis in Quercus suber L. Physiologia Plantarum 85:30-34

8. Manzanera JA, Astorga R, Bueno MA (1993) Somatic embryo induction and germination in Quercus suber L. Silvae Genetics 42:90-93

9. Hernández I, Celestino C, Toribio M (2003) Vegetative propagation of Quercus suber L. by somatic embryogenesis. I: Factors affecting the induction in leaves from mature cork oak trees. Plant Cell Reports 21:759-764

10. Pintos B, Manzanera JA, Bueno MA (2010) Oak somatic and gametic embryos maturation is affected by charcoal and specific aminoacids mixture. Ann For Sci $67: 205$

11. García-Martín G, Manzanera JA, González-Benito E (2005) Effect of exogenous ABA on embryo maturation and quantification of endogenous levels of $\mathrm{ABA}$ and IAA in Quercus suber somatic embryos. Plant Cell Tissue and Organ Culture 80:171-177

12. Gómez-Garay A, López JA, Camafeita E, Bueno MA, Pintos B (2013) Proteomic perspective of Quercus suber somatic embryogenesis. J Proteomics 93:314-325.

13. Gómez-Garay A, López JA, Pintos B, Camafeita E, Bueno MA (2009) Proteomic analysis from haploid and diploid embryos of Quercus suber L. identifies qualitative and quantitative differential expression patterns. Proteomics 9:43554367

14. Bueno MA, Gómez A, Sepulveda F, Seguí JM, Testillano PS, Manzanera JA, Risueño MC (2003) Microspore-derived embryos from Quercus suber anthers mimic zygotic embryos and maintain haploidy in long-term anther culture. Journal of plant physiology 160 (8):953-960.

15. Ramírez C, Testillano PS, Pintos B, Moreno-Risueño MA, Bueno MA, Risueño MC (2004) Changes in pectins and MAPKs related to cell development during early 
microspore embryogenesis in Quercus suber L. European journal of cell biology $83(5): 213-225$

16. Rodríguez-Sanz H, Manzanera JA, Solís MT, Gómez-Garay A, Pintos B, Risueño MC, Testillano PS (2014) Early markers are present in both embryogenesis pathways from microspores and immature zygotic embryos in cork oak, Quercus suber L. BMC Plant Biology 14 (1):224.

17. Murashige T, Skoog F (1962) A revised medium for rapid growth and bio assays with tobacco tissue cultures. Physiologia Plantarum 15 (3):473-497.

18. Sommer HE, Brown CL, Kormanik PP (1975) Differentiation of plantles in longleaf pine (Pinus palustris Mill.) tissue culture in vitro. Botanical Gazette 136:196-200 
Table 1: Micronutrients of MS medium

\begin{tabular}{|c|c|c|c|}
\hline Component & $\begin{array}{l}\text { Stock solution } \\
\text { concentration }(\mathrm{g} / \mathrm{l})\end{array}$ & $\begin{array}{l}\text { Volume of stock for } \\
1 \text { liter of medium }\end{array}$ & $\begin{array}{l}\text { Final concentration } \\
\text { in medium }(\mathrm{mg} / \mathrm{l})\end{array}$ \\
\hline $\mathrm{FeSO}_{4} \cdot 7 \mathrm{H}_{2} \mathrm{O}$ & 2.78 & $10 \mathrm{ml}$ & 27.8 \\
\hline $\mathrm{Na}_{2}$ EDTA & 3.75 & $10 \mathrm{ml}$ & 37.5 \\
\hline $\mathrm{H}_{3} \mathrm{BO}_{3}$ & 0.62 & $10 \mathrm{ml}$ & 6.2 \\
\hline $\mathrm{MnSO}_{4} \cdot \mathrm{H}_{2} \mathrm{O}$ & 1.69 & $10 \mathrm{ml}$ & 16.9 \\
\hline $\mathrm{ZnSO}_{4} \cdot 7 \mathrm{H}_{2} \mathrm{O}$ & 0.86 & $10 \mathrm{ml}$ & 8.6 \\
\hline $\mathrm{KI}$ & 0.083 & $10 \mathrm{ml}$ & 0.83 \\
\hline $\mathrm{Na}_{2} \mathrm{MoO}_{4} \cdot 2 \mathrm{H}_{2} \mathrm{O}$ & 0.025 & $10 \mathrm{ml}$ & 0.25 \\
\hline $\mathrm{CuSO}_{4} \cdot 4 \mathrm{H}_{2} \mathrm{O}$ & 0.0625 & $10 \mathrm{ml}$ & 0.625 \\
\hline $\mathrm{CoCl}_{2} \cdot 6 \mathrm{H}_{2} \mathrm{O}$ & 0.6025 & $10 \mathrm{ml}$ & 6.025 \\
\hline
\end{tabular}

Table 2: Vitamins and aminoacids of MS medium

\begin{tabular}{|l|c|c|c|}
\hline Component & $\begin{array}{l}\text { Stock solution } \\
\text { concentration }(\mathrm{g} / \mathrm{l})\end{array}$ & $\begin{array}{l}\text { Volume of stock for } \\
\text { 1 liter of medium }\end{array}$ & $\begin{array}{l}\text { Final concentration } \\
\text { in medium }(\mathrm{mg} / \mathrm{l})\end{array}$ \\
\hline Glycine & 0.2 & $10 \mathrm{ml}$ & 2.0 \\
\hline Myoinositol & 10 & $10 \mathrm{ml}$ & 100 \\
\hline Nicotinic acid & 0.5 & $10 \mathrm{ml}$ & 5.0 \\
\hline Pyridoxine-HCl & 0.5 & $10 \mathrm{ml}$ & 5.0 \\
\hline Thiamine-HCl & 0.1 & $10 \mathrm{ml}$ & 1.0 \\
\hline Ascorbic acid & 0.2 & $10 \mathrm{ml}$ & 2.0 \\
\hline
\end{tabular}

Table 3: Macronutrients of Sommer medium

\begin{tabular}{|l|c|c|c|}
\hline Component & $\begin{array}{l}\text { Stock solution } \\
\text { concentration }(\mathrm{g} / \mathrm{l})\end{array}$ & $\begin{array}{l}\text { Volume of stock for } \\
\text { 1 liter of medium }\end{array}$ & $\begin{array}{l}\text { Final concentration } \\
\text { in medium }(\mathrm{mg} / \mathrm{l})\end{array}$ \\
\hline $\mathrm{KNO}_{3}$ & 100 & $10 \mathrm{ml}$ & 1000 \\
\hline $\mathrm{NaH}_{2} \mathrm{PO}_{4} \cdot 2 \mathrm{H}_{2} \mathrm{O}$ & 12.95 & $10 \mathrm{ml}$ & 129.5 \\
\hline $\mathrm{MgSO}_{4} \cdot 7 \mathrm{H}_{2} \mathrm{O}$ & 25 & $10 \mathrm{ml}$ & 250 \\
\hline $\mathrm{SO}_{4}\left(\mathrm{NH}_{4}\right)_{2}$ & 20 & $10 \mathrm{ml}$ & 200 \\
\hline $\mathrm{KCl}$ & 30 & $10 \mathrm{ml}$ & 300 \\
\hline $\mathrm{CaCl}_{2} \cdot 2 \mathrm{H}_{2} \mathrm{O}$ & 15 & $10 \mathrm{ml}$ & 150 \\
\hline
\end{tabular}

Table 4: Composition of media for somatic embryogenesis of Quercus suber L.

\begin{tabular}{|c|c|c|c|}
\hline Induction medium & Proliferation medium & Maturation medium & $\begin{array}{l}\text { Germination } \\
\text { medium }\end{array}$ \\
\hline 2,4-D $(0.5 \mathrm{mg} / \mathrm{l})$ & & Act. charcoal $(10 \mathrm{~g} / \mathrm{l})$ & $\mathrm{BA}(50 \mathrm{mg} / \mathrm{l})$ \\
\hline Glutamine $(0.5 \mathrm{~g} / \mathrm{l})$ & Glutamine $(0.5 \mathrm{~g} / \mathrm{l})$ & Glutamine $(0.5 \mathrm{~g} / \mathrm{l})$ & IBA $(0.1 \mathrm{mg} / \mathrm{l})$ \\
\hline Sucrose $(30 \mathrm{~g} / \mathrm{l})$ & Sucrose $(30 \mathrm{~g} / \mathrm{l})$ & Sucrose $(30 \mathrm{~g} / \mathrm{l})$ & Sucrose $(15 \mathrm{~g} / \mathrm{l})$ \\
\hline Agar $(8 \mathrm{~g} / \mathrm{l})$ & Agar $(8 \mathrm{~g} / \mathrm{l})$ & Agar $(8 \mathrm{~g} / \mathrm{l})$ & Agar $(10 \mathrm{~g} / \mathrm{l})$ \\
\hline \multicolumn{4}{|c|}{ Sommer Macronutrients } \\
\hline \multicolumn{4}{|c|}{ MS Micronutrients } \\
\hline \multicolumn{4}{|c|}{ MS vitamins and aminoacids } \\
\hline \multicolumn{2}{|c|}{ pH5.6 }
\end{tabular}




\section{Figure legends}

\section{Figure 1: Main stages of somatic embryogenesis of Quercus suber.}

A) Immature zygotic embryo, at the beginning of the culture. B) Induction of somatic embryogenesis: embryogenic masses and early embryos emerge from the explants surface (arrows). C) Early torpedo embryo (lateral view) formed by direct embryogenesis and emerging from the explants. D) Proliferation period: clumps of embryogenic masses of different sizes and groups of embryos of various developmental stages showing recurrent embryogenesis. E) Immature cotyledonary embryo formed during the proliferation period. F) Mature cotyledonary embryo. G) Plantlet regenerated in vitro after germination of a mature somatic embryo. $\mathrm{H}$ ) Acclimatization ex-vitro of a plant regenerated from somatic embryogenesis. Bars in A, B, C: 1mm; in D, E, F: $2 \mathrm{~mm}$.

Figure 2: Cellular organization during induction and progression of somatic embryogenesis of Quercus suber.

Samples of somatic embryogenesis cultures at different stages after fixation and Technovit resin embedding, for microscopy analysis. Micrographs of semithin sections stained by toluidine blue and observed in a light microscope under bright field. A) Rounded masses of embryogenic cells (arrows) emerging from the surface of the explants. B) High magnification of embryogenic cells showing characteristic features. C) Globular embryo. D) Initiation of secondary embryogenesis by formation of a new protrusion of embryogenic cells from somatic embryos. E) Developing heart-shaped embryo. Bars in A, B: $50 \mu \mathrm{m}$, in C: $100 \mu \mathrm{m}$, in D, E: $200 \mu \mathrm{m}$. 

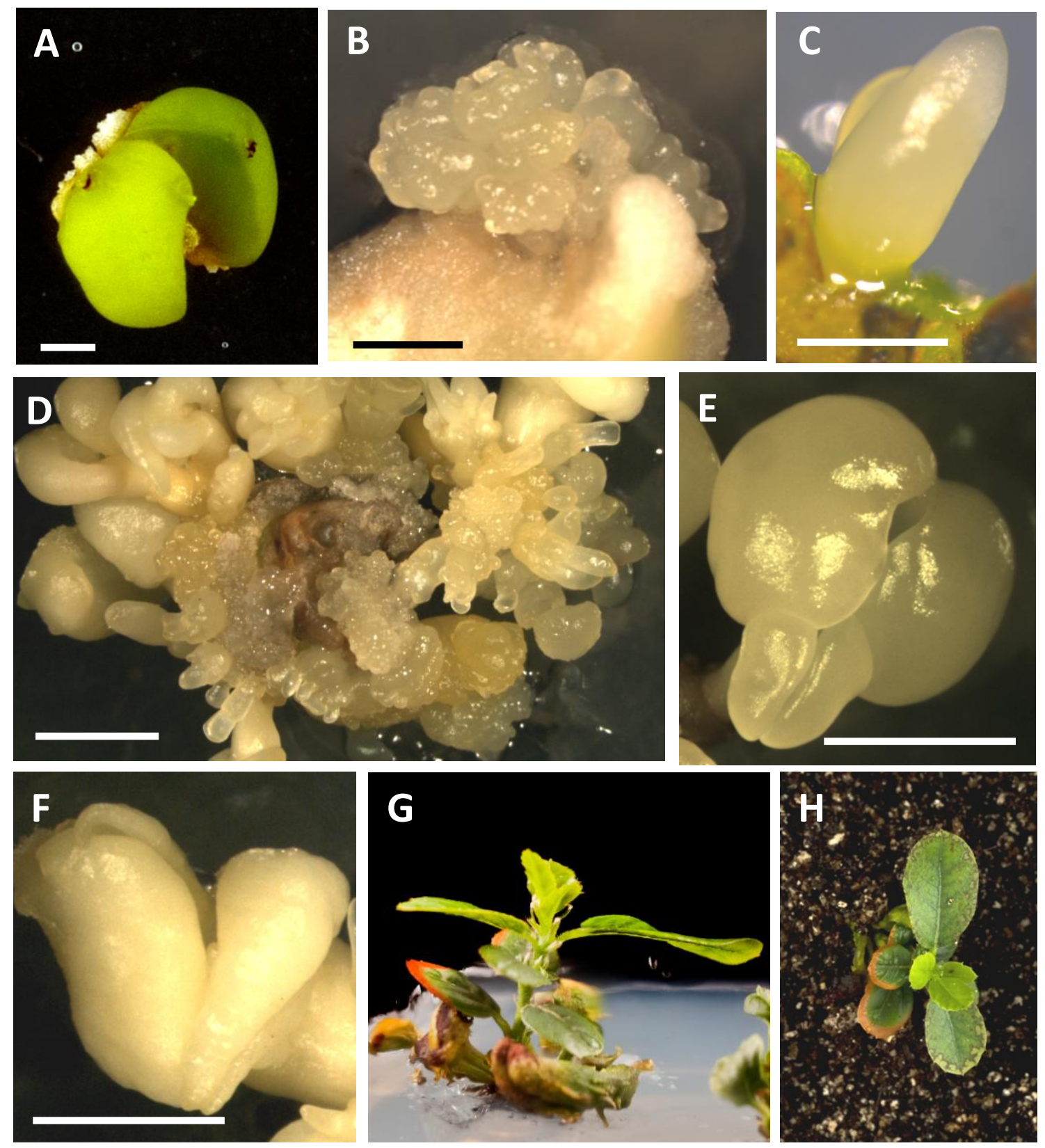

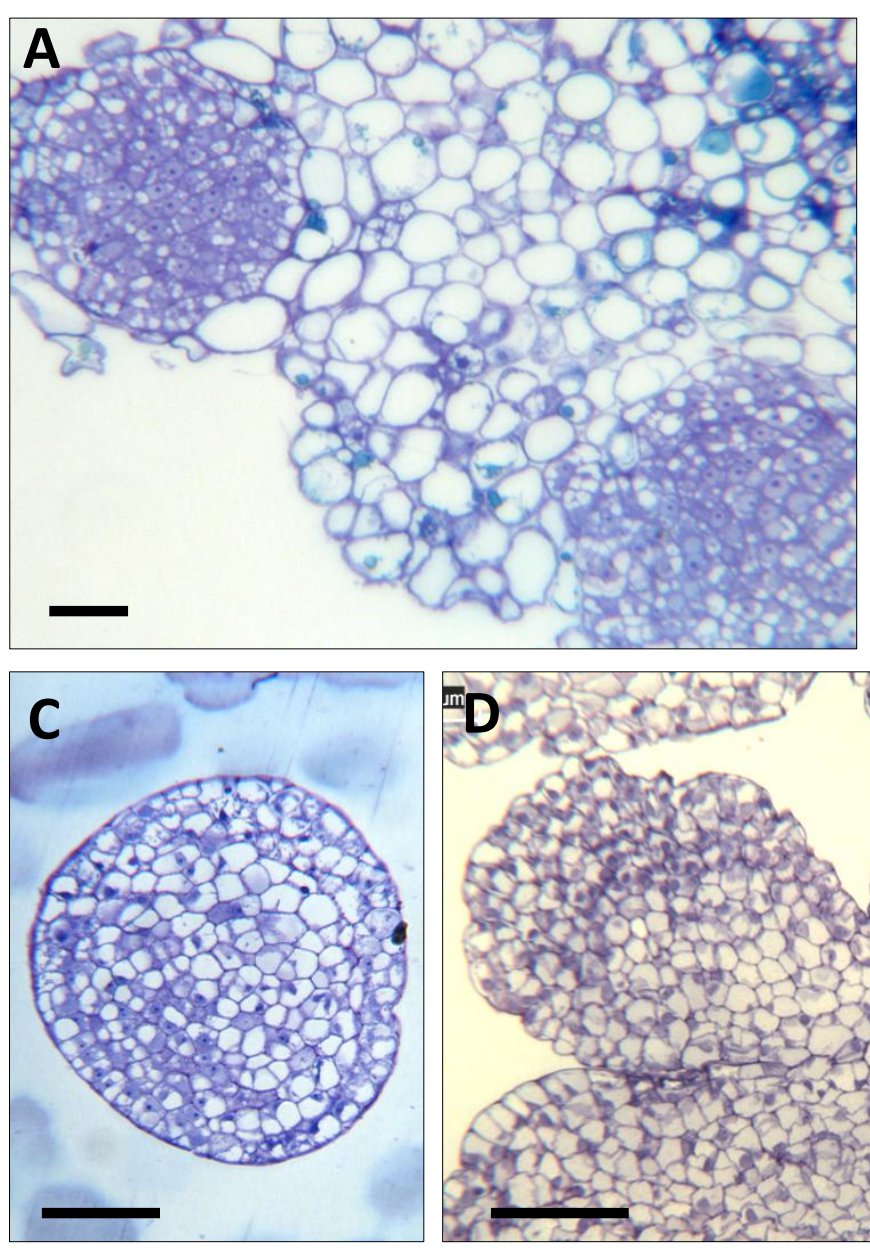
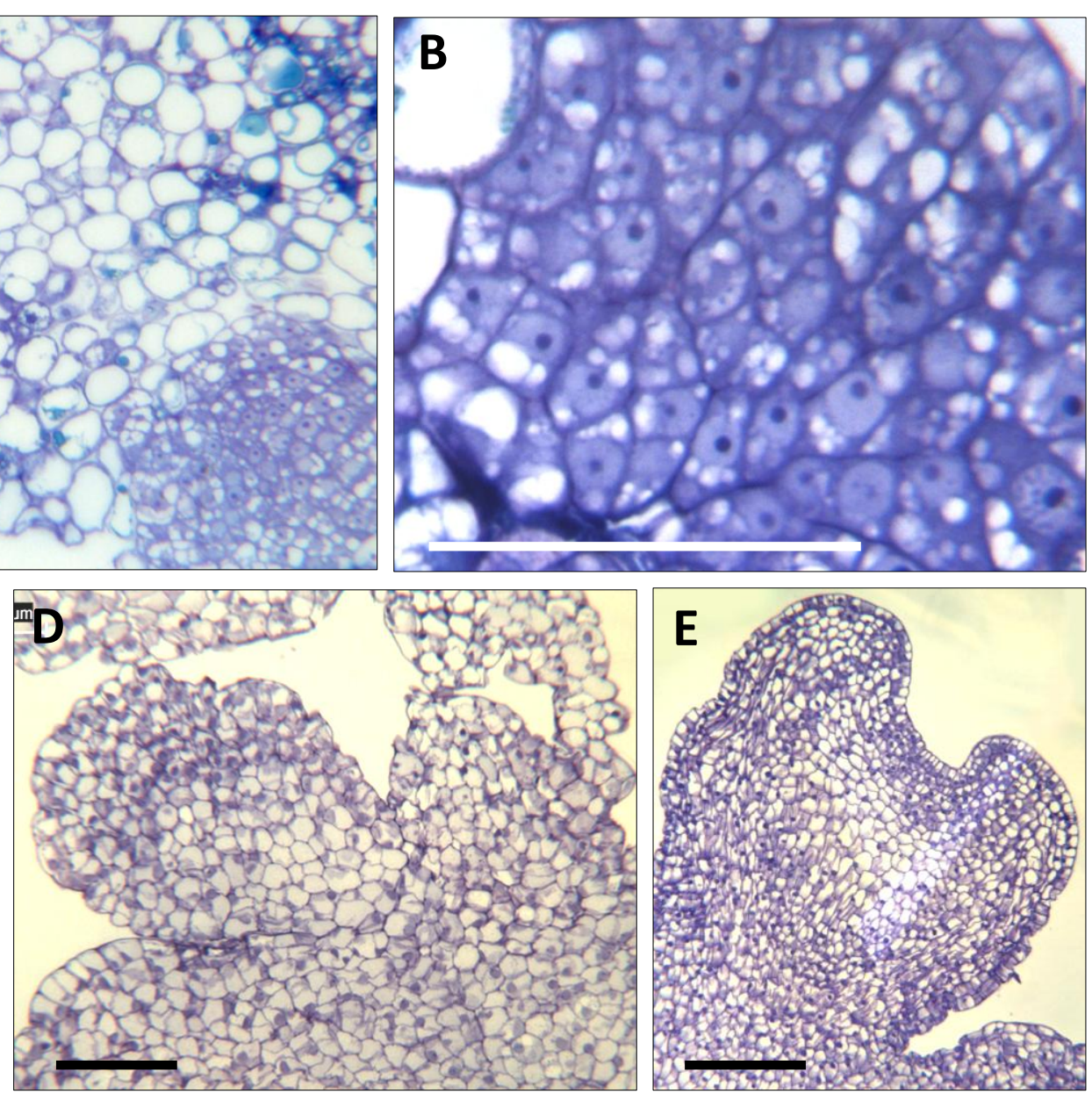

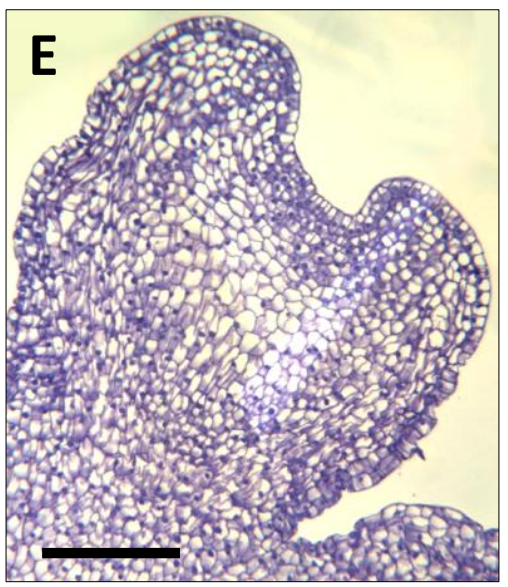

